\title{
Diversity of clinically relevant Fusarium species complexes: preliminary analysis of an 11-yr prospective surveillance in France
}

D. Garcia-Hermoso, K.Sitbon, C. Gautier, F. Lanternier, O. Lortholary, F. Dromer, S. Bretagne and the French Mycoses Study Group.

Institut Pasteur, Unité de Mycologie Moléculaire, Centre National de Référence Mycoses Invasives et Antifongiques (NRCMA), Paris, France

\section{BACKGROUND /OBJECTIVES}

Fusarium spp. are implicated in human and animal infections with many different clinical manifestations, from keratitis to deeper infections. At least six species complexes (SC) have been involved in these infections. Our aim was to dissect the association between clinical manifestations and Fusarium species using the surveillance systems implemented in France since 2005 at the NRCMA.

\begin{tabular}{lllcc}
\hline \multicolumn{2}{c}{$\begin{array}{c}\text { Type of surveillance } \\
\text { system at the NRCMA }\end{array}$} & Period & $\begin{array}{c}\# \\
\text { hospitals }\end{array}$ & $\begin{array}{c}\# \\
\text { cases }\end{array}$ \\
\hline RESSIF & active & $\begin{array}{l}2012- \\
2016\end{array}$ & 26 & 154 \\
RESOMYC semi-passive & $\begin{array}{l}2005- \\
2016\end{array}$ & 54 & 228 \\
\hline
\end{tabular}

\section{METHODS}

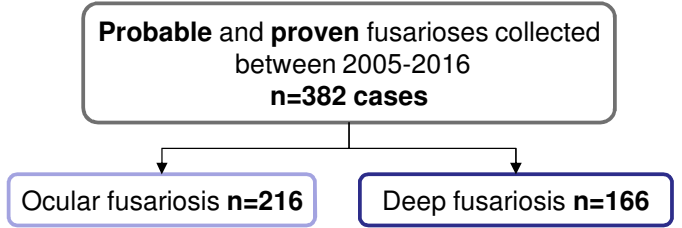

- The phylogenetic analysis of strains was based on DNA sequence data for the elongation factor $1-\alpha(T E F-1 \alpha)$ and the RNA polymerase II subunit ( $R \boldsymbol{P B 2}$ ) regions.

- Antifungal susceptibility testing was performed for 8 antifungals according to EUCAST recommendations.

\section{RESULTS I}

MAJOR DIFFERENCES between ocular and deep FUSARIOSIS

\begin{tabular}{llll}
\hline \multicolumn{1}{c}{ Fusariosis } & $\begin{array}{l}\text { OCULAR } \\
(\mathrm{n}=216)\end{array}$ & $\begin{array}{l}\text { DEEP } \\
(\mathrm{n}=166)\end{array}$ & $\mathrm{p}$ \\
\hline Male ratio & $39 \%$ & $60 \%$ & $<0.001$ \\
$\begin{array}{l}\text { Median age } \pm \text { IQR } \\
\begin{array}{l}\text { Underlying } \\
\text { immunosuppression }\end{array}\end{array}$ & $39 \pm 27$ & $56 \pm 28$ & $<0.001$ \\
Local injury & $97.3 \%$ & $78.3 \%$ & \\
\hline
\end{tabular}

- Among the 216 ocular cases, keratitis and corneal ulcer were the main presentations. The wear of contact lenses was reported in $146(68 \%)$ cases with a female predominance. Fusarium oxysporum SC was the main species recovered $(44 \%)$.

- In deep infections ( $n=166)$, fungemia was present in $43 \%$ associated predominantly to immunosuppression (hematological malignancies, solid tumors and SOT)

- Elevated MICs values for the four complexes were observed for azoles, candins and AMB EXCEPT for F. dimerum SC which had lower values for voriconazole, amphotericin $B$ and terbinafin

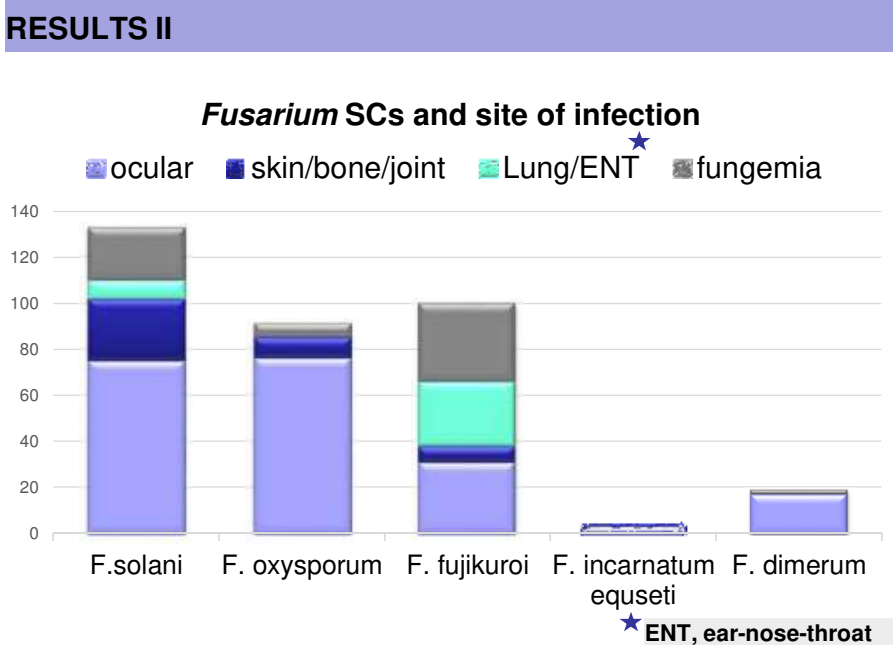

EF1-alpha topology for 347 strains (202 ocular, 145 deep)

Fusarium fujikuroi SC $\mathrm{n}=100$

-F. proliferatum as the most frequent species $(50 \%)$ -Predominant in DEEP INFECTIONS (lung $28 \%$; blood 34\%)

-Associated with dissemination in $49 \%$ of cases compared to non disseminated cases

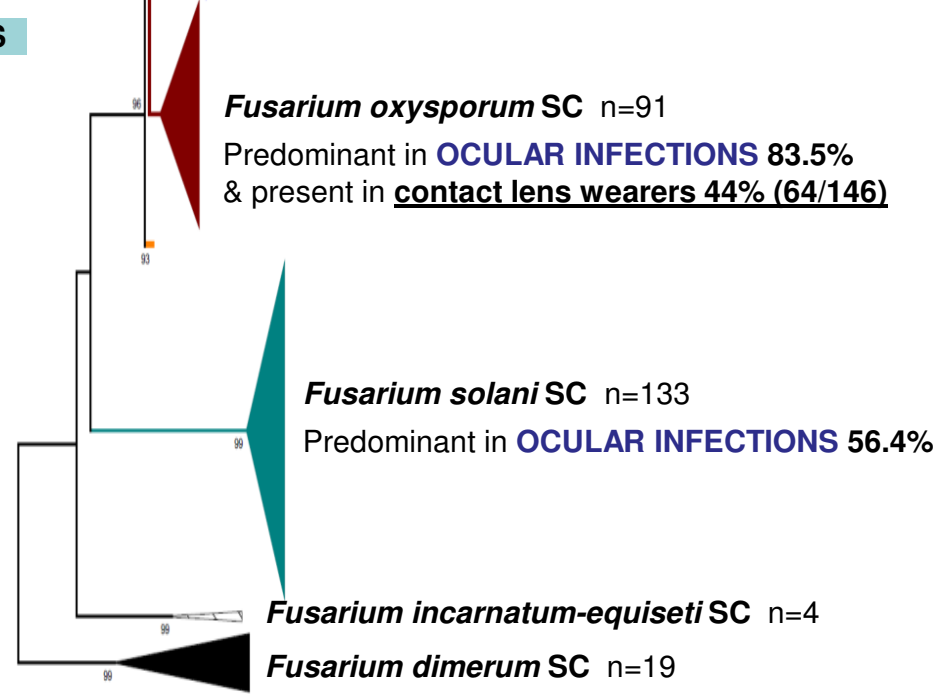

\section{DISCUSSION/PERSPECTIVES}

Association between clinical manifestations and Fusarium complexes in a large cohort $(n=382)$ of patients

- Members of the $\boldsymbol{F}$. fujikuroi SC were significantly associated with immunocompromised patients and disseminated fusariosis

- Studies to investigate these preferential associations are ongoing. 